\title{
Bacillus methanolicus sp. nov., a New Species of Thermotolerant, Methanol-Utilizing, Endospore-Forming Bacteria
}

\author{
NICO ARFMAN, ${ }^{1}$ LUBBERT DIJKHUIZEN, ${ }^{1 *}$ GUDRUN KIRCHHOF, ${ }^{2}$ WOLFGANG LUDWIG, ${ }^{2}$ \\ KARL-HEINZ SCHLEIFER, ${ }^{2}$ EUGENIA S. BULYGINA, ${ }^{3}$ KONSTANTIN M. CHUMAKOV, ${ }^{3}$ \\ NATALYA I. GOVORUKHINA, ${ }^{4}$ YURI A. TROTSENKO, ${ }^{4}$ \\ DUNCAN WHITE, ${ }^{5}$ AND RICHARD J. SHARP ${ }^{5}$ \\ Department of Microbiology, University of Groningen, NL-9751 NN Haren, The Netherlands ${ }^{1}$; Lehrstuhl für \\ Mikrobiologie, Technische Universität München, D-8000 Munich, Germany ${ }^{2}$; Institute of Microbiology, \\ Academy of Sciences, 117811 Moscow, ${ }^{3}$ and Institute of Biochemistry and Physiology of Microorganisms, \\ Puschino, Moscow Region, ${ }^{4}$ Russia; and Public Health Laboratory Service Centre for Applied Microbiology \\ and Research Division of Biotechnology, Porton Down, Salisbury, Wiltshire SP4 0JG, United Kingdom ${ }^{5}$
}

\begin{abstract}
The generic position of 14 strains of gram-positive bacteria able to use methanol as a growth substrate was determined. All are obligately aerobic, thermotolerant organisms that are able to grow at temperatures of 35 to $60^{\circ} \mathrm{C}$. Nine of the strains produce oval spores at a subterminal-to-central position in slightly swollen rod-shaped cells. DNA-DNA hybridization studies, 5S rRNA sequence analysis, and physiological characteristics revealed that all 14 strains cluster as a well-defined group and form a distinct new genospecies. Analysis of the $16 \mathrm{~S}$ and $5 \mathrm{~S}$ rRNA sequences indicated that this new species is distinct from Bacillus brevis but closely related to $B$. firmus and $B$. azotoformans. The name proposed for this new species is $B$. methanolicus. The type strain, PB1, has been deposited in the National Collection of Industrial and Marine Bacteria as NCIMB 13113.
\end{abstract}

Bacteria able to grow on methanol at elevated temperatures are of technological interest for single-cell protein production, solvent degradation in aerobic thermophilic biotreatment processes, and fermentative production of amino acids $(1,25,42)$. Following an earlier report on growth of a mixed culture with spore-forming bacteria on methanol (45), a claim appeared in the patent literature (31) concerning Bacillus strains that grow on methanol with optimum growth temperatures of ca. $55^{\circ} \mathrm{C}$ and maximum growth temperatures of ca. $65^{\circ} \mathrm{C}$. In recent years, several other groups have successfully employed continuous culture techniques for isolation of pure cultures of Bacillus strains that grow rapidly on methanol at $55^{\circ} \mathrm{C}(5,15,24,29,42)$. Metabolism of methanol, ethanol, and glucose $(7,9,23,47)$ and environmental control of metabolic fluxes $(2-4,14,15,30)$ have been studied in detail in these organisms, grown in batch and continuous cultures under a variety of nutrient limitations and steady-state as well as transient-state conditions. The methylotrophic Bacillus strains display a strong resistance to high methanol concentrations, and the molar growth yields on methanol at the optimum growth temperatures in methanol-limited chemostats are among the highest reported for methylotrophic bacteria $(6,24)$. Enzyme analysis revealed that all isolates employ a novel NAD-dependent methanol dehydrogenase for methanol oxidation and the ribulose monophosphate pathway for formaldehyde assimilation (79).

On the basis of a number of phenotypic tests, Al-Awadhi et al. (5) concluded that seven of their isolates were Bacillus brevis strains. A further isolate was a sheathed, filamentous, gram-positive, endospore-forming, obligately aerobic bacterium that could not be allocated to any previously described

\footnotetext{
* Corresponding author.
}

genus. In the present investigation, 14 organisms, including most of Al-Awadhi's isolates, were further characterized, and a classification of these strains based on various properties, including DNA-DNA hybridization, is proposed.

\section{MATERIALS AND METHODS}

Test strains and cultivation conditions. The thermotolerant methanol-utilizing Bacillus strains PB1 (NCIMB 13113), C1 (NCIMB 13114), AR2, TS1, TS2, and TS4, isolated by Dijkhuizen et al. (24); 4(55) (NCIMB 12523), S1 (NCIMB 12524), WM5.2 (NCIMB 12525), TFB (NCIMB 12526), WM5.1 (NCIMB 12527), S2 (NCIMB 12528), and KA (NCIMB 12529), isolated by $\mathrm{Al}$-Awadhi et al. (5); and 40M, isolated by Govorukhina and Trotsenko (29), were the subject of chemotaxonomic, molecular systematic, and phenotypic tests. The mesophilic trimethylamine-utilizing Bacillus strain S2A1 (19) was included in the 5S rRNA sequence analysis. The nonmethylotrophs $B$. firmus DSM 12 and $B$. brevis DSM 30 were used as reference strains in some of the physiological tests. All strains were stored without supplements as frozen stocks at $-80^{\circ} \mathrm{C}$ and routinely grown in Tryptone soya broth (TSB; Oxoid CM131; 30 g/liter) adjusted to $\mathrm{pH} 7.5$. For plates, TSB was solidified with $1.5 \%$ (wt/vol) agar (TSBA). Growth of the methylotrophic Bacillus strains in batch cultures and carbon-, oxygen- or nitrogenlimited continuous cultures has been described previously $(7,9,14)$. DNA, 16S rRNA, 5S rRNA, cell wall fractions, fatty acids, and lipids were isolated from cells grown in batch cultures in trimethylamine $(25 \mathrm{mM}$; strain $\mathrm{S} 2 \mathrm{~A} 1$ only) or methanol (100 mM; all other strains) mineral medium supplied with vitamins (24).

Morphology. Colony morphology was examined in isolated colonies grown on TSBA for 2 days at $55^{\circ} \mathrm{C}$. Cellular 
1 UUUUUGGAGA GUUUGAUCCU GGCUCAGGAC GAACGCUGGC GGCGUGCCUA AUACAUGCaA

61 gucgaacgGA CUGAUGGGAG CUUGCUCCCU GAAGUCAGCG GCGGACGGGU GAGUAACACG

121 UGGGCAACCU GCCUGUAAGA CCGGGAUAAC UUCGGGAAAC CGGAGCUAAU ACCGGAUAAU 181 CCUCUUUCCC GCAUGGGAAA GAGCUGAAAG AUGGCUUCGG CUAUCACUUA CAGAUGGGCC 241 CGCGGCGCAU UAGCUAGUUG GUGAGGUAAC GGCUCACCAA GGCGACGAUG CGUAGCCGAC 301 CUGAGAGGGU GAUCGGCCAC ACUGGGACUG AGACACGGCC CAGACUCCUA CGGGAGGCAG 361 CAGUAGGGAA UCUUCCGCAA UGGACGAAAG UCUGACGGAG CAACGCCGCG UGAGCGAAGA 421 AGGCCUUCGG GUCGUAAAGC UCUGUUGUCA GGGAAGAACA AGUACCGUUC GAAUAGGGC 481 GUACUUUGAC GGUACCUAAC CAGAAAGCCA CGGCUAACUA CGUGCCAGCA GCCGCGGUAA 541 UACGUAGGUG GCAAGCGUUG UCCGGAAUUA UUGGGCGUAA AGCGCGCGCA GGCGGUUCCU 601 UAAGUCUGAU GUGAAAGCCC ACGGCUCAAC CGUGGAGGGU CAUUGGAAAC UGGGGAACUU 661 GAGUGCAGAA GAGGAGAGCG GAAUUCCACG UGUAGCGGUG AAAUGCGUAG AGAUGUGGAG 721 GAACACCAGU GGCGAAGGCG GCUCUCUGGU CUGUAACUGA CGCUGAGGCG CGAAAGCGUG 781 GGGAGCAAAC AGgAUUAGAU ACCCUGGUAG UCCACGCCGU AAACGAUGAG UGCUAAGUGU 841 UAGAGGGUUU CCGCCCUUUA GUGCUGCAGC UAACGCAUUA AGCACUCCGC CUGGGGAGUA 901 CGGCCGCAAG GCUGAAACUC AAAGGAAUUG ACGGGGGCCC GCACAAGCGG UGGAGCAUGU 951 GgUUUAAUUC GAAGCAACGC GAAGAACCUU ACCAGGUCUU GACAUCCUCU GACAAUCCUG

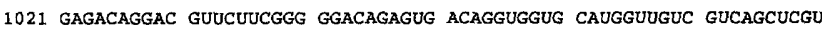
1081 GUCGUGAGAU GUUGGGUUAA GUCCCGCAAC GAGCGCAACC CUUGACCUUA GUUGCCAGCA 1141 UUCAGUUGGG CACUCUAAGG UGACUGCCGG UGACAAACCG GAGGAAGGUG GGGAUGACGU 1201 CAAAUCAUCA UGCCCCUUAU GACCUGGGCU ACACACGUGC UACAAUGGAU GGUACAAAGG 1261 GCUGCGAGAC CGCGAGGUUG AGCCAAUCCC AAAAAACCAU UCUCAGUUCG GAUUGCAGGC 1321 UGCAACUCGC CUGCAUGAAG CCGGAAUCGC UAGUAAUCGC GGAUCAGCAU GCCGCGGUGA 1381 AUACGUUCCC GGGCCUUGUA CACACCGCCC GUCACACCAC GAGAGUUUGU AACACCCGAA 1441 GUCGGUGAGG UAACCGUAAG GAGCCAGCCG CCUAAGGUGG GACAGAUGAU UGGGGUGAAG 1501 UCGUAACAAG GUAGCCGUAU CGGAAGGUGC GGCUGGAUCA CCUCCUUUCU

FIG. 1. 16S rRNA sequence of $B$. methanolicus sp. strain $C 1$. Lowercase letters indicate nucleotides whose assignment is uncertain. Underlined boldface regions are target sites of sequencing or amplification primers. morphology was examined in gram-stained smears of these cultures. Cell dimensions were measured by a calibrated eyepiece graticule. Cell diameters were recorded as being either less than $1 \mu \mathrm{m}$ (code $=0$ ) or greater than $1 \mu \mathrm{m}$ (code $=2$ ). Cell lengths were recorded as either less than $1 \mu \mathrm{m}$ (code $=0)$, between 4 and $6 \mu \mathrm{m}($ code $=1)$, or greater than $6 \mu \mathrm{m}$ (code $=2$ ). Spore morphology was examined in cultures grown on mannitol mineral medium plates $(1 \%$ [wt/vol] mannitol, 1.5\% [wt/vol] agar) for 5 days. The mineral medium used was that described by Dijkhuizen et al. (24).

Physiological tests. Tests with the thermotolerant methylotrophic Bacillus strains were performed at $55^{\circ} \mathrm{C}$. Tests with reference strains $B$. firmus and $B$. brevis were performed at $37^{\circ} \mathrm{C}$. All tests were inoculated with overnight peptone water broth cultures derived from overnight plate cultures. Acid production from sugars and sugar alcohols and hippurate hydrolysis were detected by using the media and methods of Gordon et al. (28). Degradation of casein (1\% [wt/vol], skim milk) was determined in TSBA; clearing of the medium surrounding the growth was scored as positive. Starch $(1 \%$ [wt/vol], soluble) hydrolysis was detected in the same basal medium by flooding the plates with an iodine solution (28). Nitrate and nitrite reduction, growth in $0.02 \% \mathrm{NaN}_{3}$, oxidase reaction, and the presence of amylase were examined by the methods of Cowan (20). Tolerance to saline was determined by inoculating bottles containing $10 \mathrm{ml}$ of TSB supplemented with 2 or $5 \%$ (wt/vol) $\mathrm{NaCl}$. Tolerance to acid $\mathrm{pH}$ was tested by adjusting TSB to $\mathrm{pH} 6.0$ or 6.5 . The abilities of strains to use mannitol, cellobiose, pyruvate, acetate, succinate, methanol, ethanol, and isopropanol were determined by using mineral medium supplied with a vitamin mixture (24). The substrates tested were added to a final concentration of $1 \%(\mathrm{wt} / \mathrm{vol})$, and the $\mathrm{pH}$ was adjusted to 7.5. All physiological tests were performed in triplicate, and

TABLE 1. 16S rRNA sequence similarity values for $B$. methanolicus $\mathrm{C} 1$ and other bacilli ${ }^{a}$

\begin{tabular}{|c|c|c|c|c|c|c|c|c|c|c|c|c|c|c|c|c|}
\hline \multirow[b]{2}{*}{ Organism } & \multicolumn{16}{|c|}{ \% Similarity to: } \\
\hline & 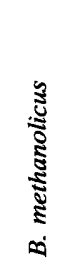 & 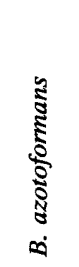 & $\sum_{\infty}^{-5}$ & $\frac{\widehat{\Xi}}{\text { है }}$ & 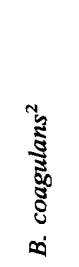 & 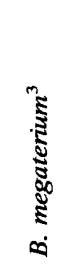 & 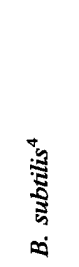 & 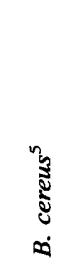 & $\begin{array}{l}0 \\
5 \\
5 \\
5 \\
0 \\
0 \\
0 \\
0 \\
0\end{array}$ & 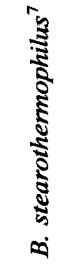 & 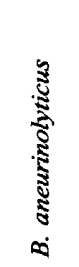 & $\begin{array}{l}5 \\
5 \\
5 \\
5 \\
5 \\
5 \\
5\end{array}$ & $\begin{array}{l}5 \\
5 \\
5 \\
0\end{array}$ & 胥 & 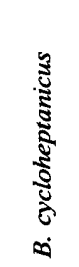 & $\begin{array}{l}\text { ठี } \\
\text { வ் }\end{array}$ \\
\hline B. methanolicus & & 96.3 & 96.1 & 95.7 & 95.4 & 95.4 & 95.4 & 94.1 & 92.8 & 93.7 & 91.5 & 90.1 & 90.2 & 89.0 & 85.9 & 78.8 \\
\hline B. azotoformans & 96.1 & & 96.1 & 95.7 & 93.9 & 95.4 & 94.8 & 94.3 & 93.1 & 92.5 & 92.5 & 90.8 & 90.9 & 89.6 & 85.6 & 706 \\
\hline B. firmus ${ }^{1}$ & 95.9 & 96.0 & & 96.3 & 94.9 & 95.8 & 94.9 & 94.5 & 93.5 & 92.0 & 91.8 & 89.9 & 88.9 & 90.2 & 85.4 & 78 \\
\hline$B$. lentus & 95.5 & 95.4 & 96.2 & & 95.3 & 95.5 & 94.3 & 94.7 & 93.4 & 92.3 & 91.7 & 89.3 & 88.7 & 89.5 & 84.9 & 78.8 \\
\hline B. coagulans ${ }^{2}$ & 95.1 & 93.5 & 94.7 & 95.0 & & 94.0 & 94.2 & 93.8 & 92.3 & 92.2 & 91.4 & 89.3 & 89.4 & 89.2 & 85.0 & 78.3 \\
\hline B. megaterium ${ }^{3}$ & 95.1 & 95.1 & 95.5 & 95.0 & 93.4 & & 94.2 & 94.7 & 93.0 & 91.6 & 91.1 & 90.3 & 89.0 & 89.4 & 85.2 & 79.0 \\
\hline B. subtilis ${ }^{4}$ & 94.9 & 94.8 & 94.5 & 93.9 & 93.7 & 93.8 & & 94.3 & 91.8 & 92.0 & 90.9 & 89.1 & 88.8 & 89.1 & 85.0 & 78.0 \\
\hline B. cereus $^{5}$ & 93.7 & 94.1 & 93.8 & 94.5 & 93.3 & 94.3 & 94.0 & & 92.1 & 91.9 & 90.4 & 89.8 & 88.3 & 88.9 & 85.0 & 78.3 \\
\hline B. globisporus ${ }^{6}$ & 92.5 & 92.8 & 93.1 & 93.1 & 92.0 & 92.6 & 91.3 & 91.8 & & 91.3 & 90.8 & 88.3 & 88.1 & 88.7 & 84.5 & 78 \\
\hline B. stearothermophilus ${ }^{7}$ & 93.3 & 92.2 & 91.7 & 91.8 & 91.8 & 91.3 & 91.6 & 91.3 & 89.9 & & 90.6 & 88.1 & 88.4 & 88.1 & 85.8 & 78. \\
\hline B. aneurinolyticus & 91.1 & 92.3 & 91.5 & 91.3 & 90.9 & 90.7 & 90.5 & 90.0 & 89.3 & 90.2 & & 90.0 & 89.8 & 89.2 & 85.2 & 78 \\
\hline B. laterosporus & 90.1 & 90.6 & 89.8 & 89.1 & 89.1 & 90.1 & 89.0 & 89.5 & 87.8 & 87.9 & 89.6 & & 94.1 & 88.5 & 83.6 & 78 \\
\hline B. brevis & 90.1 & 90.6 & 88.5 & 88.3 & 89.1 & 88.8 & 88.6 & 88.2 & 87.8 & 88.3 & 89.6 & 94.0 & & 87.2 & 82.7 & 77 \\
\hline B. polymyxa ${ }^{8}$ & 88.9 & 89.2 & 90.0 & 89.3 & 89.0 & 88.9 & 88.6 & 88.2 & 88.3 & 87.7 & 88.9 & 88.4 & 87.1 & & 85.6 & 77.8 \\
\hline B. cycloheptanicus & 85.9 & 85.4 & 84.9 & 84.4 & 84.5 & 84.8 & 84.7 & 84.6 & 84.1 & 85.8 & 84.9 & 83.6 & 83.2 & 85.4 & & 77.1 \\
\hline E. coli & 78.3 & 79.5 & 78.4 & 78.7 & 78.2 & 78.9 & 77.9 & 78.1 & 78.8 & 78.1 & 78.3 & 78.3 & 77.4 & 77.4 & 76.6 & \\
\hline
\end{tabular}

${ }^{a}$ Mean values are given for the groups of related bacilli defined in Fig. 2 . The values on the lower left are overall similarity values; the values on the upper right are based on a set of data reduced to those positions which are invariant in at least $40 \%$ of the entire set of sequences. 


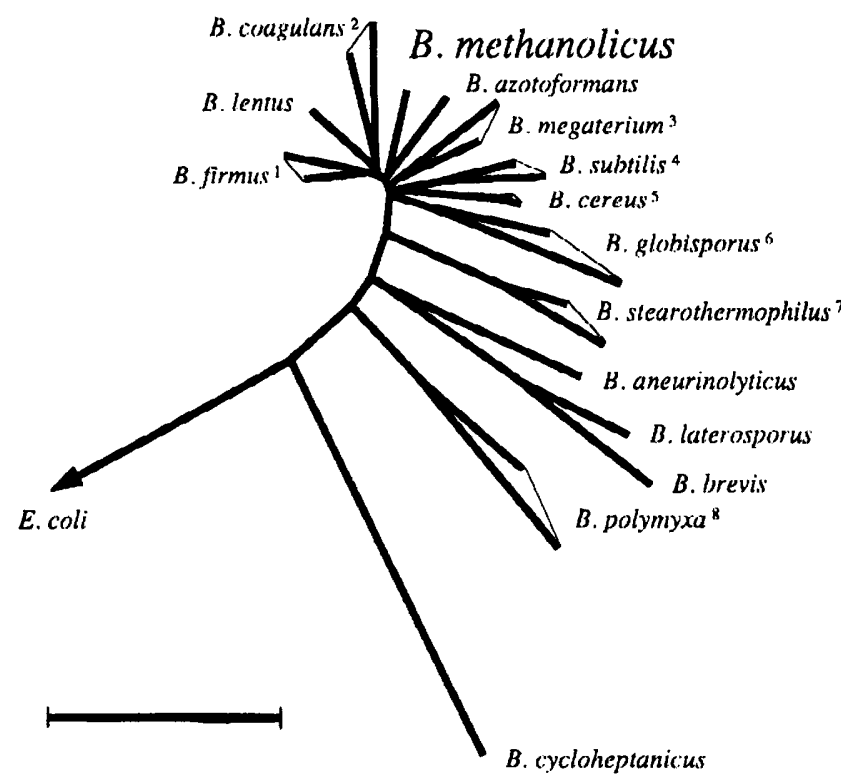

FIG. 2. Distance matrix tree showing the relationships between methanol-utilizing $B$. methanolicus $\mathrm{C} 1$ and other bacilli. The phylogenetic distances were calculated by including those alignment positions which are invariant in at least $40 \%$ of the entire set of $16 \mathrm{~S}$ rRNA sequences. Groups of more closely related bacilli whose relationships are supported by distance and parsimony analyses are indicated by triangles. These groups are as follows: $1, B$. firmus, $B$. benzoevorans, and $B$. circulans; $2, B$. coagulans, $B$. acidoterrestris, $B$. badius, and $B$. smithii; $3, B$. megaterium, $B$. fastidiosus, $B$. maroccanus, $B$. psychosaccharolyticus, and $B$. simplex; $4, B$. subtilis, $B$. amyloliquefaciens, $B$. atrophaeus, $B$. lautus, $B$. lentimorbus, $B$. licheniformis, $B$. popillae, and $B$. pumilus; $5, B$. cereus, $B$. anthracis, $B$. medusa, $B$. mycoides, and $B$. thuringiensis; $6, B$. globisporus, B. fusiformis, B. insolitus, B. pasteurii, B. psychrophilus, and B. sphaericus; $7, B$. stearothermophilus, B. kaustophilus, and $B$. thermoglucosidasius; $8, B$. polymyxa, $B$. amylolyticus, $B$. alvei, $B$. azotofixans, $B$. gordonae, $B$. larvae, $B$. macquariensis, B. macerans, B. pabuli, and B. pulvifaciens. Bar, $0.05 K_{\text {nuc }}$.

results were recorded after 1,3 , and 5 days. Poly- $\beta$-hydroxybutyric acid accumulation was determined as described by Braunegg et al. (12) and Suzuki et al. (46).

Antibiotic sensitivity. Cultures were incubated overnight in peptone water broth. Disposable bioassay plates were prepared with $200 \mathrm{ml}$ of Oxoid Sensitest agar (CM409) with 3\% (wt/vol) agar. The plates were seeded with a 3-ml culture volume and allowed to dry. Oxoid antibiotic sensitivity discs were then placed on these plates, which were incubated overnight. The zone width from the edge of the disc to the edge of the bacterial growth was then measured.

Computer analysis. Physiological and morphological data were analyzed by using the simple matching, Jaccard, and pattern difference coefficients (44). Clustering was achieved by using the unweighted pair group method with arithmetic averages algorithm (44).

Determination of $\mathbf{G}+\mathrm{C}$ contents of DNAs and DNA homology studies. Purification of DNA was performed as described by Meyer and Schleifer (37). The melting point of the purified DNA was determined by using the method of Marmur and Doty (36), and the G+C content was calculated by using the method of De Ley et al. (22). DNA from Escherichia coli B (Sigma Chemical Co., St. Louis, Mo.), with a $\mathrm{G}+\mathrm{C}$ content of $51.7 \mathrm{~mol} \%$, was used as the refer- ence. DNA-DNA hybridization studies were performed by using the DNA filter method described by Kilpper et al. and Kilpper-Bälz et al. $(33,34)$.

16S rRNA analysis. Determination of the 16S rRNA primary structure was done by direct sequencing of the RNA and sequencing of cloned in vitro-amplified rDNA. RNA was isolated from strain $\mathrm{Cl}$ as described by Embley et al. (26). Sequencing of 16S rRNA was performed by using reverse transcriptase as described by Lane et al. (35). Sequence ambiguities were resolved by using terminal transferase (21). A DNA fragment containing the greater part of a 16S rRNA gene (homologous to positions 54 to 1542 of $E$. coli $16 \mathrm{~S}$ rRNA), the intrageneric spacer, and a small 5'-terminal part of a 23S rRNA gene (homologous to positions 1 to 130 of $E$. coli $23 \mathrm{~S}$ rRNA) was amplified in vitro by applying the polymerase chain reaction technique (41) in combination with site-specific primers (5'-CATGCAAGTCGARCG-3' [16S rRNA specific] and 5'-GGGTTYCCCCATTCGG-3' [23S rRNA specific]). The amplified rDNA fragment was cloned as pC1-611-118 in the vector pBluescript (Stratagene, La Jolla, Calif.). DNA sequencing was done as described by Chen and Seeburg (17). Oligonucleotide primers were synthesized by standard methods by using a Biosearch Cyclone DNA synthesizer. The sequences of these primers are complementary to highly conserved regions of 16S rRNA. The new sequence was added to an alignment of about 500 almost complete 16S rRNA primary structures of (eu)bacteria. Alignment of sequences was performed with respect to conserved primary structures, as well as secondary structures. Phylogenetic distance values $\left(K_{\text {nuc }} ; 32\right)$ were calculated, including those positions which had been determined for both of the particular sequence pairs. Phylogenetic trees were reconstructed by applying the distance, parsimony, and bootstrapped parsimony methods by using the programs NEIGHBOR, FITCH, DNAPARS, and DNABOOT as implemented in Felsenstein's PHYLIP program package (27).

5S rRNA analysis. Isolation, sequencing, and phylogenetic analysis of 5S ribosomal RNA were performed by published procedures $(16,18)$.
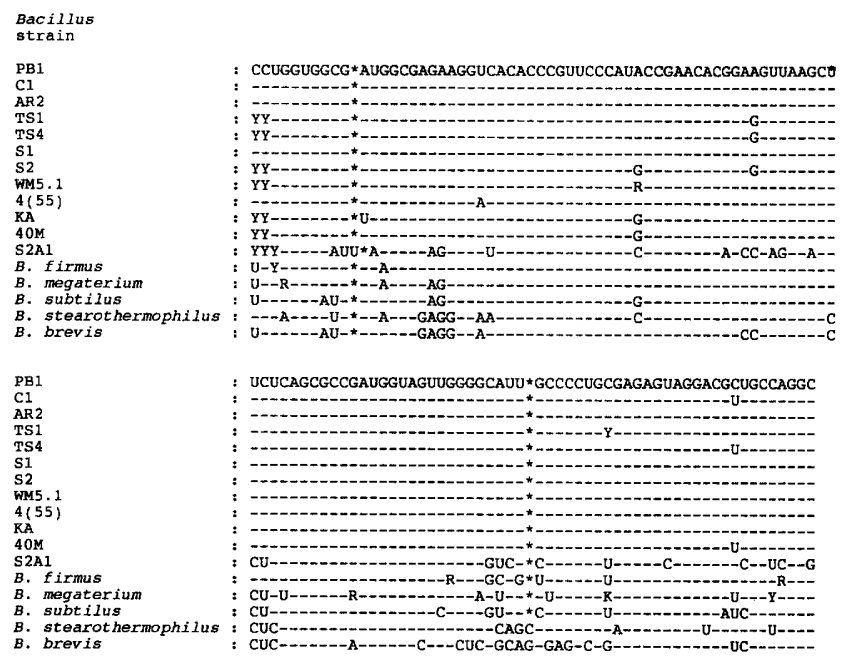

FIG. 3. Alignment of 5S rRNA sequences of methylotrophic bacteria (determined in this study) and $B$. firmus ATCC 14575, $B$. megaterium KM, B. subtilis 168, B. stearothermophilus 799, and $B$. brevis ATCC 8185 (49). Only nucleotides that differ from the Bacillus strain PB1 sequence are shown. Asterisks indicate alignment gaps. Y, C or U; R, A or G; K, G or U. 
TABLE 2. Physiological characteristics of thermotolerant methylotrophic Bacillus strains, ${ }^{a} B$. firmus, and $B$. brevis ${ }^{b}$

\begin{tabular}{|c|c|c|c|c|c|c|c|c|c|c|c|c|c|c|}
\hline \multirow{2}{*}{ Test } & \multicolumn{12}{|c|}{ Result obtained with Bacillus sp. strain: } & \multirow{2}{*}{$\begin{array}{l}\text { B. firmus } \\
\text { result }\end{array}$} & \multirow{2}{*}{$\begin{array}{l}\text { B. brevis } \\
\text { result }\end{array}$} \\
\hline & $\overline{\mathrm{C} 1}$ & PB1 & AR2 & TS1 & TS2 & TS4 & S1 & S2 & TFB & WM5.1 & WM5.2 & $\overline{\mathrm{KA}}$ & & \\
\hline \multicolumn{15}{|l|}{ Fermentation of: } \\
\hline Fructose & 0 & 0 & 2 & 0 & 2 & 2 & 0 & 0 & 0 & 0 & 0 & 0 & - & - \\
\hline Glycerol & 0 & 0 & 0 & 0 & 0 & 0 & 0 & 0 & 0 & 0 & 0 & 0 & 2 & 0 \\
\hline Glycogen & 0 & 0 & 0 & 0 & 0 & 0 & 0 & 0 & 0 & 0 & 0 & 0 & 0 & 1 \\
\hline Inulin & 0 & 0 & 0 & 0 & 0 & 0 & 0 & 0 & 0 & 0 & 0 & 0 & 2 & 2 \\
\hline Lactose & 0 & 0 & 0 & 0 & 0 & 0 & 0 & 0 & 0 & 0 & 0 & 0 & 0 & 1 \\
\hline Maltose & 2 & 2 & 2 & 0 & 2 & 2 & 2 & 2 & 0 & 2 & 2 & 2 & - & - \\
\hline Mannitol & 2 & 2 & 2 & 2 & 2 & 2 & 2 & 2 & 2 & 2 & 2 & 2 & 0 & 1 \\
\hline Raffinose & 2 & 2 & 2 & 0 & 0 & 0 & 0 & 2 & - & 2 & 2 & 2 & 0 & 0 \\
\hline Ribose & 2 & 2 & 0 & 2 & 0 & 0 & 0 & 2 & 0 & 2 & 2 & 0 & - & - \\
\hline Salicin & 0 & 0 & 0 & 0 & 0 & 0 & 0 & 0 & 0 & 0 & 0 & 0 & 0 & 2 \\
\hline Sorbitol & 0 & 2 & 0 & 0 & 0 & 0 & 2 & - & 2 & 0 & 2 & - & 0 & 2 \\
\hline Starch & 0 & 0 & 0 & 0 & 0 & 0 & 0 & 0 & 0 & 0 & 0 & 0 & 1 & 1 \\
\hline Sucrose & 0 & 0 & 0 & 0 & 0 & 0 & 0 & 0 & 0 & 0 & 0 & 0 & 2 & 2 \\
\hline Trehalose & 2 & 0 & 2 & 0 & 2 & 2 & 0 & 0 & 2 & 0 & 0 & 0 & 0 & 0 \\
\hline \multicolumn{15}{|l|}{ Growth on: } \\
\hline Methanol & 2 & 2 & 2 & 2 & 2 & 2 & 2 & 2 & 2 & 2 & 2 & 2 & 0 & 0 \\
\hline Acetate & - & 0 & 0 & 2 & 0 & 0 & - & 0 & 0 & 0 & 0 & 0 & - & - \\
\hline Ethanol & 2 & 0 & 2 & 2 & 2 & 2 & 0 & - & 0 & 0 & - & 0 & - & - \\
\hline Pyruvate & 2 & 0 & 2 & - & 2 & 2 & 0 & 2 & 1 & 0 & 0 & 0 & - & - \\
\hline Isopropanol & 0 & 0 & 1 & 0 & 2 & 0 & 0 & 0 & 0 & 0 & 0 & - & - & - \\
\hline \multicolumn{15}{|l|}{ Growth in: } \\
\hline $2 \% \mathrm{NaCl}$ & 2 & 0 & 2 & 2 & 2 & 2 & 0 & 2 & 0 & 2 & 2 & 2 & - & - \\
\hline $0.02 \% \mathrm{NaN}_{3}$ & 0 & 0 & 1 & 2 & 2 & 1 & 0 & 0 & 2 & 2 & 0 & 1 & 2 & 0 \\
\hline $\begin{array}{l}\text { Growth at } \mathrm{pH} \\
\quad 6.0\end{array}$ & 1 & 0 & 0 & 0 & 0 & 0 & 0 & 0 & 0 & 0 & 0 & 0 & 2 & 0 \\
\hline \multicolumn{15}{|l|}{ Hydrolysis of: } \\
\hline Casein & 0 & 0 & 0 & 0 & 0 & 0 & 0 & 0 & 0 & 0 & 0 & 0 & 1 & 2 \\
\hline Starch & 1 & 0 & 1 & 0 & 1 & 1 & 2 & 1 & 2 & 0 & 0 & 0 & 2 & 2 \\
\hline \multicolumn{15}{|l|}{$\begin{array}{l}\text { Colony } \\
\text { morphology }\end{array}$} \\
\hline Transparent & 2 & 0 & 2 & 2 & 2 & 2 & 2 & 0 & 2 & 0 & 0 & 0 & - & - \\
\hline Rough & 2 & 2 & 2 & 2 & 2 & 2 & 2 & 0 & 2 & 2 & 2 & 0 & - & - \\
\hline Raised $^{c}$ & 0 & 2 & 0 & 0 & 0 & 0 & 0 & 0 & 0 & 2 & 2 & 0 & - & - \\
\hline Crenated $^{d}$ & 2 & 2 & 2 & 2 & 2 & 2 & 2 & 0 & 2 & 2 & 2 & 0 & - & - \\
\hline \multicolumn{15}{|l|}{$\begin{array}{l}\text { Cellular } \\
\text { morphology }\end{array}$} \\
\hline Diameter & 0 & 2 & 0 & 0 & 0 & 0 & 2 & 2 & 2 & - & 2 & 0 & 2 & 2 \\
\hline Length & 1 & 1 & 2 & 1 & 2 & 1 & 1 & 1 & 0 & - & 1 & 2 & 0 & 2 \\
\hline Filaments & 0 & 2 & 2 & 0 & 2 & 2 & 0 & 0 & 0 & - & 0 & 2 & 0 & 2 \\
\hline Chains $^{e}$ & 0 & 2 & 0 & 0 & 0 & 0 & 0 & 0 & 0 & - & 2 & 2 & 0 & 0 \\
\hline
\end{tabular}

a All strains produced acid from glucose but not from $i$-erythritol, inositol, xylose, galactose, or adonitol. All strains grew at pH 6.5 and displayed oxidase activity. All methanol-utilizing bacilli showed catalase activity. None of the strains hydrolyzed hippurate or were able to reduce nitrate or nitrite. No growth was observed in the presence of $5 \% \mathrm{NaCl}$. The methylotrophic bacilli grew on mannitol but failed to grow on succinate or cellobiose (B. brevis and $B$. firmus were not tested). All colonies contained nonmotile, rod-shaped cells that stained positive in the Gram test. The methylotrophic bacilli grew at temperatures between 35 and $60^{\circ} \mathrm{C}$.

$b$ Scores: 2 , positive; 1 , weakly positive; 0 , negative; - , test not done or results unsatisfactory. Scores for cell lengths are described in Materials and Methods.

$c$ Score 0 , colony is flat.

${ }^{d}$ Score 0 , colony is convex.

e Score 0 , single cells.

Other analytical methods. Preparation of cell wall fractions and determination of the diamino acid were carried out as described by Schleifer and Kandler (43). Fatty acid, lipid, and hopanoid extraction and analysis were carried out as described by Bringer et al. (13).

Nucleotide sequence accession numbers. The 16S rRNA sequence has been deposited in the EMBL data library under accession number X64465. The 5S rRNA sequences have been deposited in the EMBL data library under accession numbers Z11816 to Z11827.

\section{RESULTS AND DISCUSSION}

16S rRNA sequence. The 16S rRNA primary structure of strain $\mathrm{C} 1$ is shown in Fig. 1. The sequence was compared with all published homologous sequences of bacilli $(10,11$, 
TABLE 3. Antibiotic sensitivity of thermotolerant methylotropic Bacillus strains, B. firmus, and B. brevis

\begin{tabular}{|c|c|c|c|c|c|c|c|c|c|c|c|c|c|c|}
\hline \multirow{2}{*}{ Antibiotic $^{a}$} & \multicolumn{12}{|c|}{ Sensitivity ${ }^{b}$ of strain: } & \multirow{2}{*}{$\begin{array}{l}\text { B. firmus } \\
\text { sensitivity }\end{array}$} & \multirow{2}{*}{$\begin{array}{l}\text { B. brevis } \\
\text { sensitivity }\end{array}$} \\
\hline & $\mathrm{Cl}$ & PB1 & AR2 & TS1 & TS2 & TS4 & S1 & S2 & TFB & WM5.1 & WM5.2 & $\overline{\mathrm{KA}}$ & & \\
\hline S3 500 & 2 & 2 & 0 & 0 & 0 & 0 & 1 & 2 & 2 & 2 & 2 & 2 & 0 & 0 \\
\hline OB5 & 2 & $\overline{1}$ & 1 & 1 & 1 & 1 & 1 & 1 & 1 & 2 & 2 & 2 & 1 & 1 \\
\hline E10 & - & 2 & 1 & 2 & 2 & 2 & 1 & 2 & 2 & 2 & 2 & 2 & 1 & 1 \\
\hline VA5 & 1 & 2 & 2 & - & 1 & 1 & $\overline{1}$ & 1 & 1 & - & 1 & 1 & 1 & 1 \\
\hline NV5 & 1 & 1 & 1 & 1 & - & 1 & - & 1 & 1 & 2 & 1 & 1 & 1 & 1 \\
\hline N10 & 2 & 1 & 1 & 1 & 1 & - & 1 & 1 & 1 & 2 & 1 & 1 & 1 & 1 \\
\hline PB300 & 1 & 2 & 1 & 1 & 1 & 1 & 1 & 1 & 1 & 2 & 2 & 1 & 1 & 1 \\
\hline FD10 & 2 & 2 & 1 & - & 1 & 1 & 2 & 1 & 1 & 2 & 1 & 1 & 1 & 1 \\
\hline AMP10 & 1 & 1 & 1 & 1 & 1 & 1 & 1 & 1 & 1 & 1 & 1 & 1 & 1 & 1 \\
\hline $\mathrm{C} 30$ & 1 & 1 & 1 & 1 & 1 & 1 & 1 & 1 & 1 & 1 & 1 & 1 & 1 & 1 \\
\hline CN10 & 1 & 1 & 1 & 1 & 1 & 1 & 1 & 1 & 1 & 1 & 1 & 1 & 1 & 1 \\
\hline K5 & 1 & 1 & 1 & 1 & 1 & 1 & 1 & 1 & 1 & 1 & 1 & 1 & 1 & 1 \\
\hline $\mathrm{S} 10$ & 1 & 1 & 1 & 1 & 1 & 1 & 1 & 1 & 1 & 1 & 1 & 1 & 1 & 1 \\
\hline TE10 & 1 & 1 & 1 & 1 & 1 & 1 & 1 & 1 & 1 & 1 & 1 & 1 & 1 & 1 \\
\hline W5 & 1 & 1 & - & 0 & - & 1 & 1 & 1 & 1 & 1 & 1 & 1 & 1 & 1 \\
\hline
\end{tabular}

${ }^{a}$ S3 500, compound sulfonamide $(500 \mu \mathrm{g})$; OB5, cloxacillin $(5 \mu \mathrm{g})$; E10, erythromycin (10 $\left.\mu \mathrm{g}\right)$; VA5, vancomycin $(5 \mu \mathrm{g})$; NV5, novobiocin (5 $\left.\mu \mathrm{g}\right)$; N10,

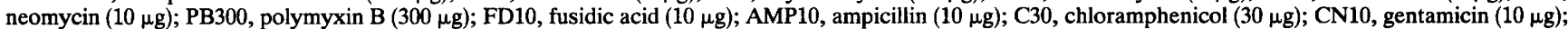
$\mathrm{K} 5$, kanamycin $(5 \mu \mathrm{g})$; S10, streptomycin $(10 \mu \mathrm{g})$; TE10, tetracycline $(10 \mu \mathrm{g})$; W5, trimethoprim $(5 \mu \mathrm{g})$.

${ }^{b} 2$, highly sensitive; 1 , sensitive; 0 , not sensitive; - , test not done or unsatisfactory.

40, 48). A matrix of sequence similarity values is shown in Table 1. Mean values are given for groups of more closely related bacilli. The phylogenetic tree shown in Fig. 2 is based on a matrix of phylogenetic distances which had been calculated by including those alignment positions which are invariant in at least $40 \%$ of the entire set of sequences. The combined 16S rRNA data show that Bacillus strain $\mathrm{C1}$ is more closely related to $B$. azotoformans and $B$. firmus than to $B$. brevis, as originally thought (5).

DNA-DNA hybridization studies. DNA-DNA hybridization studies showed that the thermotolerant methanol-utilizing Bacillus strains are closely related and form a distinct taxon. The DNA similarity values obtained at optimal hybridization conditions $\left(25^{\circ} \mathrm{C}\right.$ below the $T_{m}$ of the homologous hybridization) were $60 \%$ and higher.

5S rRNA sequences. 5S rRNA sequences of the methylotrophic bacteria determined in this investigation are shown in Fig. 3. These sequences were compared with published data on nonmethylotrophic mesophilic and thermophilic Bacillus species (49). The 5S rRNA data confirm that the thermotolerant methanol-utilizing Bacillus strains cluster as a well-defined group, separate from mesophilic trimethylamine-utilizing Bacillus strain S2A1 and nonmethylotrophic thermophilic organisms such as B. stearothermophilus. The 5S rRNA data also provide further evidence that the thermotolerant methylotrophic bacilli are closely related to $B$. firmus and $B$. megaterium but not to B. brevis.

Morphology and physiological characteristics. All of the methanol-utilizing strains studied were obligately aerobic and able to grow in various media at temperatures of 35 to $60^{\circ} \mathrm{C}$. Their physiological characteristics are listed in Tables 2 and 3. All strains formed circular colonies on TSBA after 2 days of incubation, in most cases with rough surfaces and crenated, undulating edges. Colonies of strains S2 and KA were different with respect to most of the properties tested (Table 2) (5). All colonies contained nonmotile, rod-shaped cells that stained gram positive. Strain KA forms filamentous cells during all growth stages. Some of the other isolates also formed filamentous cells but only towards the end of growth, e.g., in the centers of TSBA colonies. In methanol-limited continuous cultures of strains $\mathrm{C} 1$ and AR2, most of the cells were present as short chains of rod-shaped cells. Reduced growth rates caused formation of strongly helical filaments (data not shown) in both of these cultures. Similar cellular structures were detected in colonies of all of the methylotrophic isolates grown on mannitol mineral agar for 2 days. Under these conditions, however, they constituted only a minority of the population. With the exception of strains $\mathrm{C} 1$, TS1, TS2, WM5.2, and TFB, cells of all of the strains sporulated on TSBA and/or on mannitol mineral agar. Sporulating cells were swollen and possessed oval spores at a subterminal-to-central position. The $\mathrm{G}+\mathrm{C}$ content of the DNAs of strains C1, PB1, AR2, TS1, TS4, S2, 4(55), WM5.1, and KA was determined as 48 to $50 \%$. The above data indicate that all endospore-forming isolates may be assigned to the genus Bacillus (39).

Previously, we reported (24) that isolation of these methanol-utilizing strains in pure cultures was difficult when methanol agar plates were used. This may be due to accumulation of toxic formaldehyde from methanol. With various alternative techniques, six methanol-utilizing strains were isolated (strains PB1, C1, AR2, TS1, TS2, and TS4). All six initially produced subterminal oval endospores, but some strains lost this ability upon subcultivation, resulting in isolation of endospore-deficient mutants. All of these methylotrophic Bacillus strains contained meso-diaminopimelic acid as a cell wall diamino acid. This murein type is also present in the cell walls of $B$. subtilis, $B$. pumilus, $B$. megaterium, $B$. cereus, $B$. firmus, $B$. fastidiosus, and $B$. brevis (43). Lipid analysis indicated the presence of squalene and phosphatidylethanolamine in strain $\mathrm{C} 1$. Hopanoids (38) were not detected. The fatty acid profile of strain $\mathrm{Cl}$ consists mainly of 13-methyltetradecanoic acid (iso- $\mathrm{C}_{15} ; 27 \%$ of total fatty acid composition), 12-methyltetradecanoic acid (anteiso- $\mathrm{C}_{15} ; 16 \%$ ), 14-methylpentadecanoic acid (iso- $\mathrm{C}_{16}$; $12 \%$ ), 13-methylpentadecanoic acid (anteiso- $\mathrm{C}_{16} ; 13 \%$ ), 15methylhexadecanoic acid (iso- $\mathrm{C}_{17} ; 4 \%$ ), and 14-methylhexadecanoic acid (anteiso- $\mathrm{C}_{17} ; 14 \%$ ). Cells of strains M40 and $\mathrm{C} 1$ grown on methanol in nitrogen-limited continuous cultures contained a storage polymer that was identified as poly- $\beta$-hydroxybutyric acid. Sudan black staining of cells of strains PB1 and AR2 grown on methanol in oxygen-limited 
continuous cultures revealed the presence of intracellular lipophilic material, most likely poly- $\beta$-hydroxybutyric acid. These findings suggest that the ability to synthesize poly- $\beta$ hydroxybutyric acid is a feature common to the entire group of methylotrophic Bacillus strains.

Determination of the average linkage (simple matching coefficient/unweighted pair group clustering) of the methanol-utilizing Bacillus strains on the basis of 68 characteristics (Table 2 and 3 ) revealed that all of the isolates are linked at $>80 \%$ similarity, which indicates that the strains are closely related.

The thermotolerant methylotrophic test strains can readily be separated from mesophilic $B$. firmus on the basis of growth temperature; growth at $\mathrm{pH} 6.0$; methanol utilization; acid production from glycerol, inulin, mannitol, and sucrose; and hydrolysis of casein (Table 2). B. brevis differs with respect to methanol utilization; acid production from inulin, salicin, and sucrose; and hydrolysis of casein (Table 2).

Molecular systematic, chemotaxonomic, and phenotypic data confirm that all of the 14 strains examined in this study are closely related and belong to the genus Bacillus. Until the internal heterogeneity of this group of organisms is studied in more detail, we propose that all 14 isolates be considered as belonging to a new species, for which we propose the name $B$. methanolicus.

Description of $B$. methanolicus Arfman, Dijkhuizen, Kirchhof, Ludwig, Schleifer, Bulygina, Chumakov, Govorukhina, Trotsenko, White, and Sharp sp. nov. (me.tha'noli.cus. M. L. n. methanolicum, methanol; M. L. masc. adj. methanolicus, relating to methanol). Cells are rod shaped and stain gram positive. Older cultures may contain filamentous cells. No motility has been observed. Sporulating cells are swollen and possess oval spores at a subterminal-tocentral position, although the ability to sporulate has been lost in some cultures. Growth is obligately aerobic and occurs at temperatures between 35 and $60^{\circ} \mathrm{C}$, with optimum growth at around $55^{\circ} \mathrm{C}$. The $\mathrm{G}+\mathrm{C}$ content of the DNA is 48 to $50 \mathrm{~mol} \%$. Phenotypic characteristics are shown in Tables 2 and 3. Organisms can be isolated from soil samples, aerobic (thermophilic) waste water treatment systems, and volcanic hot springs. Type strain: $B$. methanolicus PB1 NCIMB 13113.

\section{ACKNOWLEDGMENTS}

Thanks are due to N. Al-Awadhi, M. M. Attwood, A. G. Brooke, T. Egli, P. N. Green, W. Harder, and E. M. Watling for kindly providing us with strains and for valuable discussions and to $K$. Poralla for carrying out the lipid and fatty acid analyses. We also thank S. Dracheva and E. Kunin for contributing to the 5S rRNA sequence analysis.

These investigations were financially supported by the Biotechnology Action Programme of the Commission of European Communities (contract BAP-0267-NL) and the Programme Committee for Industrial Biotechnology (The Netherlands).

\section{REFERENCES}

1. Al-Awadhi, N. 1989. The characterization and physiology of some thermotolerant and thermophilic solvent-utilizing bacteria. Ph.D. thesis, Swiss Federal Institute of Technology, Zurich.

2. Al-Awadhi, N., T. Egli, and G. Hamer. 1988. Growth characteristics of a thermotolerant methylotrophic Bacillus sp. (NCIMB 12522) in batch culture. Appl. Microbiol. Biotechnol. 29:485493.

3. Al-Awadhi, N., T. Egli, G. Hamer, and C. A. Mason. 1990. The process utility of thermotolerant methylotrophic bacteria. I. An evaluation in chemostat culture. Biotechnol. Bioeng. 36:816820.

4. Al-Awadhi, N., T. Egli, G. Hamer, and C. A. Mason. 1990. The process utility of thermotolerant methylotrophic bacteria. II. An evaluation of transient responses. Biotechnol. Bioeng. 36:821825.

5. Al-Awadhi, N., T. Egli, G. Hamer, and E. Wehrli. 1989. Thermotolerant and thermophilic solvent-utilizing methylotrophic, aerobic bacteria. Syst. Appl. Microbiol. 11:207-216.

6. Anthony, C. 1982. The biochemistry of methylotrophs. Academic Press, Inc. (London), Ltd., London.

7. Arfman, N., K. J. de Vries, H. R. Moezelaar, M. M. Attwood, G. K. Robinson, M. van Geel, and L. Dijkhuizen. 1991. Regulation of methylotrophic metabolism in thermotolerant Bacillus strains during growth in batch and continuous cultures. Arch. Microbiol. 157:272-278.

8. Arfman, N., J. Van Beeumen, G. E. de Vries, W. Harder, and L. Dijkhuizen. 1991. Purification and characterization of an activator protein for methanol dehydrogenase from thermotolerant Bacillus spp. J. Biol. Chem. 266:3955-3960.

9. Arfman, N., E. M. Watling, W. Clement, R. J. van Oosterwijk, G. E. de Vries, W. Harder, M. M. Attwood, and L. Dijkhuizen. 1989. Methanol metabolism in thermotolerant methylotrophic Bacillus strains involving a novel catabolic NAD-dependent methanol dehydrogenase as a key enzyme. Arch. Microbiol. 152:280-288.

10. Ash, C., J. A. E. Farrow, M. Dorsch, E. Stackebrandt, and M. D. Collins. 1991. Comparative analysis of Bacillus anthracis, Bacillus cereus, and related species on the basis of reverse transcriptase sequencing of $16 \mathrm{~S}$ rRNA. Int. J. Syst. Bacteriol. 41:343-346.

11. Ash, C., J. A. E. Farrow, S. Wallbanks, and M. D. Collins. 1991. Phylogenetic heterogeneity of the genus Bacillus revealed by comparative analysis of small-subunit-ribosomal RNA sequences. Lett. Appl. Microbiol. 13:202-206.

12. Braunegg, G., B. Sonnleitner, and R. M. Lafferty. 1978. A rapid gas chromatographic method for the determination of poly- $\beta$ hydroxy-butyric acid in microbial biomass. Eur. J. Appl. Microbiol. Biotechnol. 6:29-37.

13. Bringer, S., T. Hartner, K. Poralla, and H. Sahm. 1985. Influence of ethanol on the hopanoid content and the fatty acid pattern in batch and continuous cultures of Zymomonas mobilis. Arch. Microbiol. 140:312-316.

14. Brooke, A. G., M. M. Attwood, and D. W. Tempest. 1990. Metabolic fluxes during the growth of thermotolerant methylotrophic Bacillus strains in methanol-sufficient chemostat cultures. Arch. Microbiol. 153:591-595.

15. Brooke, A. G., E. M. Watling, M. M. Attwood, and D. W. Tempest. 1989. Environmental control of metabolic fluxes in thermotolerant methylotrophic Bacillus strains. Arch. Microbiol. 151:268-273.

16. Bulygina, E. S., V. F. Galchenko, N. I. Govorukhina, A. I. Netrusov, D. I. Nikitin, Y. A. Trotsenko, and K. M. Chumakov. 1990. Taxonomic studies on methylotrophic bacteria by $5 \mathrm{~S}$ ribosomal RNA sequencing. J. Gen. Microbiol. 136:441-446.

17. Chen, E. Y., and P. H. Seeburg. 1985. Supercoiled sequencing: a fast and simple method for sequencing plasmid DNA. DNA $4: 165-170$.

18. Chumakov, K. M. 1987. Evolution of nucleotide sequences. Sov. Sci. Rev. Sect. D Biol. Rev. 7:51-94.

19. Colby, J., and L. J. Zatman. 1975. Tricarboxylic acid-cycle and related enzymes in restricted facultative methylotrophs. Biochem. J. 148:505-511.

20. Cowan, S. T. 1974. Cowan and Steel's manual for the identification of medical bacteria, 2nd ed. Cambridge University Press, Cambridge.

21. De Borde, D. C., C. W. Neave, M. L. Herlocher, and H. F. Massab. 1986. Resolution of a common sequencing ambiguity by terminal deoxynucleotidyl transferase. Anal. Biochem. 157: 275-282.

22. De Ley, J., H. Cattoir, and A. Reynaerts. 1970. The quantitative measurement of DNA hybridization from renaturation rates. Eur. J. Biochem. 2:133-142. 
23. Dijkhuizen, L., and N. Arfman. 1990. Methanol metabolism in thermotolerant methylotrophic Bacillus species. FEMS Microbiol. Rev. 87:215-220.

24. Dijkhuizen, L., N. Arfman, M. M. Attwood, A. G. Brooke, W. Harder, and E. M. Watling. 1988. Isolation and initial characterization of thermotolerant methylotrophic Bacillus strains. FEMS Microbiol. Lett. 52:209-214.

25. Dijkhuizen, L., T. A. Hansen, and W. Harder. 1985. Methanol, a potential feedstock for biotechnological processes. Trends Biotechnol. 3:262-267.

26. Embley, T. M., J. Smida, and E. Stackebrandt. 1988. Reverse transcriptase sequencing of ribosomal RNA from Faenia rectivingula, Pseudonocardia thermophila and Saccharopolyspora hirsuta, three cell wall type IV organisms which lack mycolic acids. J. Gen. Microbiol. 134:961-966.

27. Felsenstein, J. 1982. Numerical methods for inferring evolutionary trees. Q. Rev. Biol. 57:379-404.

28. Gordon, R. E., W. C. Haynes, and C. H.-N. Pang. 1973. The genus Bacillus (Agricultural handbook no. 427). U.S. Department of Agriculture, Washington, D.C.

29. Govorukhina, N. I., and Y. A. Trotsenko. 1989. Isolation and characterization of a thermotolerant methanol-utilizing Bacillus strains. Abstr. 6th Int. Symp. Microb. Growth $C_{1}$ Compounds, abstr. P108. University of Groningen, The Netherlands.

30. Heitzer, A., N. Al-Awadhi, and G. Hamer. 1989. Some effects of heat shocks on bacterial growth. Appl. Microbiol. Biotechnol. 30:408-414.

31. Hitzman, D. O. March 1976. U.S. patent 3,981,774.

32. Hori, H. 1975. Evolution of 5S rRNA. J. Mol. Evol. 7:75-88.

33. Kilpper, R., U. Buhl, and K.-H. Schleifer. 1980. Nucleic acid homology studies between Peptococcus saccharolyticus and various anaerobic and facultative anaerobic Gram-positive cocci. FEMS Microbiol. Lett. 8:205-210.

34. Kilpper-Bälz, R., B. L. Williams, R. Lütticken, and K.-H. Schleifer. 1984. Relatedness of "Streptococcus milleri" with Streptococcus anginosus and Streptococcus constellatus. Syst. Appl. Microbiol. 5:494-500.

35. Lane, D. J., B. Pace, G. J. Olsen, D. A. Stahl, M. L. Sogin, and N. R. Pace. 1985. Rapid determination of $16 \mathrm{~S}$ ribosomal RNA sequences for phylogenetic analyses. Proc. Natl. Acad. Sci. USA 82:6955-6959.

36. Marmur, J., and P. Doty. 1962. Determination of the base composition of deoxyribonucleic acid from its thermal denaturation temperature. J. Mol. Biol. 5:109-118.

37. Meyer, S. A., and K.-H. Schleifer. 1975. Rapid procedure for the approximate determination of the deoxyribonucleic acid base composition of micrococci, staphylococci, and other bacteria. Int. J. Syst. Bacteriol. 36:271-280.

38. Ourisson, G., M. Rohmer, and K. Poralla. 1987. Prokaryotic hopanoids and other polyterpenoid sterol surrogates. Annu. Rev. Microbiol. 41:301-333.

39. Priest, F. G., M. Goodfellow, and C. Todd. 1988. A numerical classification of the genus Bacillus. J. Gen. Microbiol. 134:18471882.

40. Rössler, D., W. Ludwig, K.-H. Schleifer, C. Lin, T. J. McGill, J. D. Wisotzkey, P. Jurtshuk, Jr., and G. E. Fox. 1991. Phylogenetic diversity in the genus Bacillus as seen by $16 \mathrm{~S}$ rRNA sequencing studies. Syst. Appl. Microbiol. 14:266-269.

41. Saiki, R. K., D. H. Gelfand, S. Stoffel, S. J. Scharf, R. Higuchi, G. T. Horn, K. G. Mullis, and E. H. Ehrlich. 1988. Primer directed enzymatic amplification of DNA with a thermostable DNA polymerase. Science 239:487-491.

42. Schendel, F. J., C. E. Bremmon, M. C. Flickinger, M. Guettler, and R. S. Hanson. 1990 . L-Lysine production at $50^{\circ} \mathrm{C}$ by mutants of a newly isolated and characterized methylotrophic Bacillus sp. Appl. Environ. Microbiol. 56:963-970.

43. Schleifer, K.-H., and O. Kandler. 1972. Peptidoglycan types of bacterial cell walls and their taxonomic implications. Bacteriol. Rev. 36:407-477.

44. Sneath, P. H., and R. R. Sokal. 1973. Numerical taxonomy. The principles and practice of numerical classification. W. H. Freeman \& Co., San Francisco.

45. Snedecor, B., and C. L. Cooney. 1974. Thermophilic mixed cultures of bacteria using methanol for growth. Appl. Microbiol. 27:1112-1117.

46. Suzuki, T., T. Yamani, and S. Shimizu. 1986. Mass production of poly- $\beta$-hydroxybutyric acid by fed-batch culture with controlled carbon/nitrogen feeding. Appl. Microbiol. Biotechnol. 24:370-374.

47. Vonck, J., N. Arfman, G. E. de Vries, J. Van Beeumen, E. F. J. van Bruggen, and L. Dijkhuizen. 1991. Electron microscopic analysis and biochemical characterization of a novel methanol dehydrogenase from the thermotolerant Bacillus sp. Cl. J. Biol. Chem. 266:3949-3954.

48. Wisotzkey, J. D., P. Jurtshuk, Jr., and G. E. Fox. 1990. PCR amplification of 16s rDNA from lyophilized cell culture facilitates studies in molecular systematics. Curr. Microbiol. 21:325327.

49. Wolters, J., and V. A. Erdmann. 1988. Compilation of 5S rRNA and 5S rRNA gene sequences. Nucleic Acids Res. 16:r1-r70. 